\title{
DESCRIPTION OF TWO NEW SPECIES OF THE GENUS TAPINOCYBA SIMON (ARANEAE : ERIGONIDAE) FROM JAPAN
}

By

\author{
Hiroshi SAITo \\ 3-772, Asahi-cho, Ashikaga City, Japan
}

Synopsis

SaIto, Hiroshi (3-772, Asahi-cho, Ashikaga City): Two new species of Tapinocyba, T. silvicultrix and $T$. oiwa from Honshu, are described. Acta arachnol., $29:$ 65-71 (1980)

In this paper I am going to describe two new species of Erigonid spiders belonging to the genus Tapinocyba baesed on the specimens which were obtained from mountanious areas in the northen part of Kanto Districts.

This genus consists of about twenty species, which are distributed in Europe and North America. YAginuma (1963) has recorded a species seemed to belong to this genus from limestone caves of Akiyoshi-dai plateau in Japan.

Before describing the species, I wish to express my hearty thanks to Dr. R. OI, Baika Women's College and Dr. T. YAGINUMA, Ohtemon Gakuin University, for their constant guidance and kind help in literature and various ways.

\section{Genus Tapinocyba SIMON 1884}

The genus Tapinocyba E. Simon is characterized as follows: Head with post-ocular sulcus (in male). Posterior eyes in a procurved line, subequal in size and Anterior eyes in a straight line, the median smaller than the lateral and separated by about the radius. Metatarsus IV without a trichobothrium. Tm I $0.42-0.55$. All tibiae with one spine, position of spines on I-III ca. 0.1.

Furthermore this study forms a line in the chain of synthetic investigation of the cultural properties in Ashikaga City. 
Male palp: Tegulum greatly developed and protuberant ventrally. The duct within the tegulum is sinuous with a sudden constriction in diameter at the end of the sinuous part.

Tapinocyba silvicultrix n. sp.

Japanese name: Yamaji-konagumo

(Figs. 1-8)

Male (holotype). Body length $1,6 \mathrm{~mm}$; Cephalothoyax $0.76 \mathrm{~mm}$ long, $0.49 \mathrm{~mm}$ wide.

Carapace chestnut brown, with slightly darker cervical grooves and radial furrows, viewed from above rather broad, the side convergent towards the front, obtusely pointed in front. Viewed from the side gently and evenly arched over the back to the posterior eyes. Clypeus slightly longer than the ocular area and strongly protruding forward (Fig. 3), Head with curved long sulci, which run backwards from posterior lateraleyes. Anterior eyes in a straight line, the median eyes smaller than the remainders and separated from each other by about the radius. Anterior medians about half the diameter of anteriorlaterals and separated from them by about 1.5 times the diameter. Posterior eyes in a procurved line, subequal in size, the median separated by a little longer than 1.5 times the diameter. Chelicerae with 5 large promarginal teeth and 5 small retromarginal teeth. Sternum brown, roundly heart-shaped, convex, broadly produced between the hind coxae. Legs yellowish brown. All tibiae with one dorsal spine; length of spines on I-III about one diameter of tibia and spine on IV about 1.5 times the diameter of tibia; position of spines on I-III ca. 0.1 and spine on IV 0.19. Metatarsi I-III with a trichobothrium, its position; Tm I 0.43 , Tm II 0.38, Tm III 0.40. Tarsal claws on I-II with conparatively developed 5 teeth.

Measurement of legs are as follows:

\begin{tabular}{cccccc}
\hline Legs & Fem. & Pat. \& Tib. & Met. & Tar. & Total \\
\hline I & 0.56 & 0.59 & 0.31 & 0.28 & 1.74 \\
II & 0.46 & 0.51 & 0.29 & 0.26 & 1.52 \\
III & 0.40 & 0.43 & 0.26 & 0.24 & 1.33 \\
IV & 0.53 & 0.63 & 0.33 & 0.25 & 1.74 \\
\hline
\end{tabular}



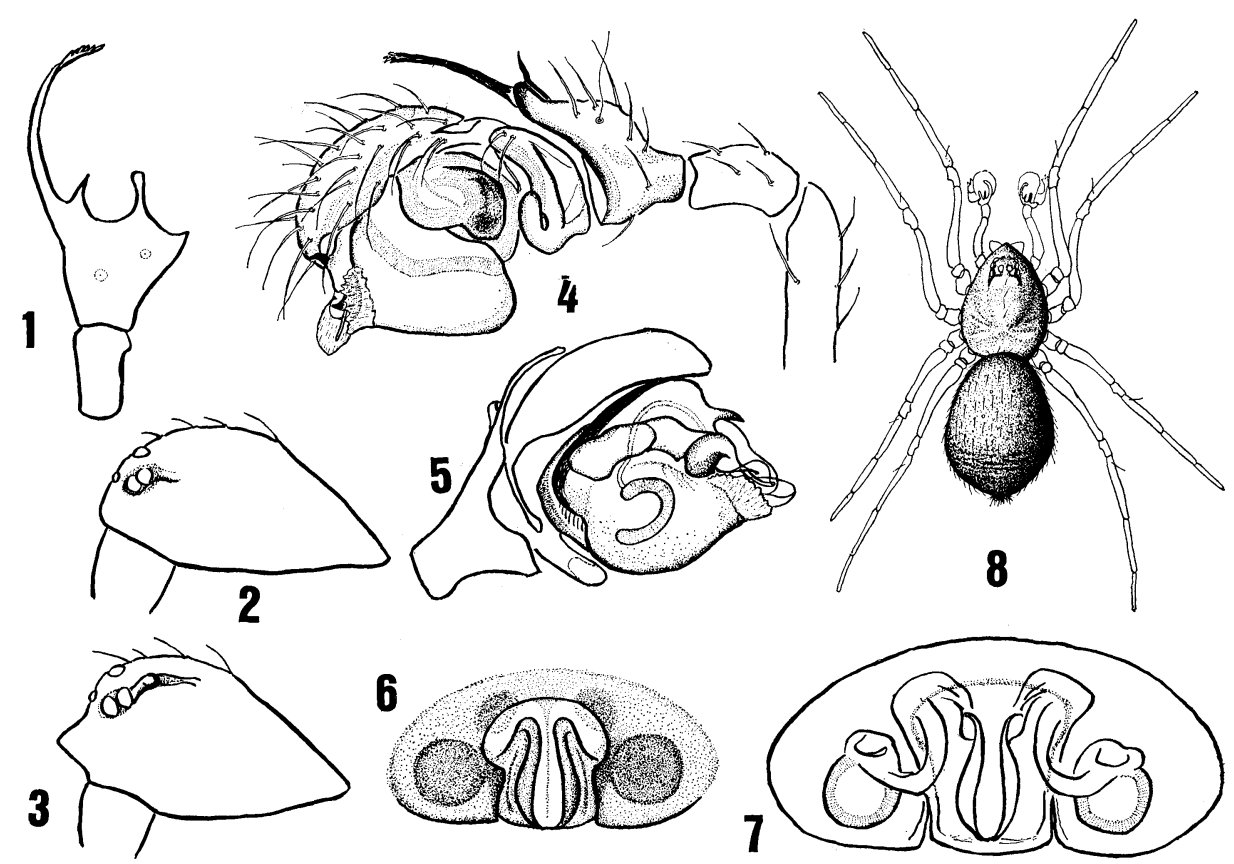

Figs. 1-8. Tapinocyba silvicultrix n. sp. 1) right palpal tibia dorsal; 2 profile 우

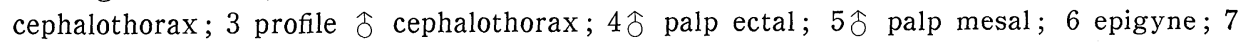
genitalia; 8 今 body dorsal.

Abdomen elongate oval, pale gray.

Male Palp. Tibia produced into three slender dorsal apophyses (Fig. 1); the inner one very long, strongly curved outward, distally crested; the middle one short and sharply pointed; the outer one short clubbed. Paracymbium short and slender, strongly curved.

Female (paratype). Body $1.5 \mathrm{~mm}$. Similar to male in form and color. Head not elevated and without sulci. Clypeus not projected. The epigynum has a wide keyhole-like opening.

Type-series. Holotype: $\uparrow$, allotype: 우, 3-VI-1976, Konuma (Mt. Akagi), Gunma Pref., H. Saito leg.

Paratype: $1 \hat{\delta}, 6$ 우, same data as the holotype; $7 \hat{\delta}, 14$ 우, 16-VI-1979, do., T. HAyashi and H. Saito leg.; 6 , , 7-VII-1977, Chuzenji, Nikko, Tochigi Pref., H. SAIto leg.; 2ㅇ, 2-V-1977, Mt. Senningatake, Ashikaga, Tocчigi Pref., H. SAITO leg. 
The holotype and one of the paratypes are preserved in the collection of the Arachnological Society of East Asia, Ohtemon-Gakuin University, Osaka. The other paratypes are distributed to the Tochigi Prefectural Museum, Utsunomiya, Dr. R. OI' s and my private collection.

Distribution. Japan (Honshu).

Remarks. This species is related to $T$. insecta, $T$. affinis and $T$. ventosa, but differs from them in the tibial apophyses of male palp and in the structure of female genitalia.

\section{Tapinocyba oiwa n. sp.}

Japanese name: Ōiwa-yamaji-konagumo

(Figs. 9-16)

Male (holotype). Body length $1.3 \mathrm{~mm}$; Cephalothorax $0.65 \mathrm{~mm}$ long, $0.49 \mathrm{~mm}$ wide.

Carapace yellowish brown, with slightly darker cervical grooves and radial furrows and has several short bristles arranged in a row in front of the median furrow. Carapace viewed from above evenly rounded on the side and pointed the front, viewed from the side rather steeply ascending behind to the cervical groove, then gently ascending in a almost straight line to the back of posterior madian eye. Head with long sulci which run nearly straight and parallel to the side. Clypeus convex, slightly shorter than the ocular area and slanting forward. Anterior eyes in a nearly straight line, the median eyes smaller than the remainders and separated from each other by about the radius. Anterior medians about half the diameter of anterior laterals, and separated from them by about 1.5 times the diameter. Anterior laterals a little larger than posterior eyes.

Posterior eyes in a procurved line, subequal in size, the median separated from each other by about 1.5 times the diameter, and separated from posterior laterals by a little longer than 1.5 times the diameter. Chelicerae brown with 5 large promarginal teeth and 5 small retromarginal teeth. Sternum pale yellow, slightly darker at the margin, a little longer than wide, convex, posterior produced between the hind coxae which are separated by the length. Legs yellowish brown. All tibiae with one dorsal spine; length of spines on I-III about one diameter of tibia, and spine on IV a little longer than the diameter of tibia; position of spines on I-III ca. 0.1 and spine on IV ca. 0.17. Metatarsi 


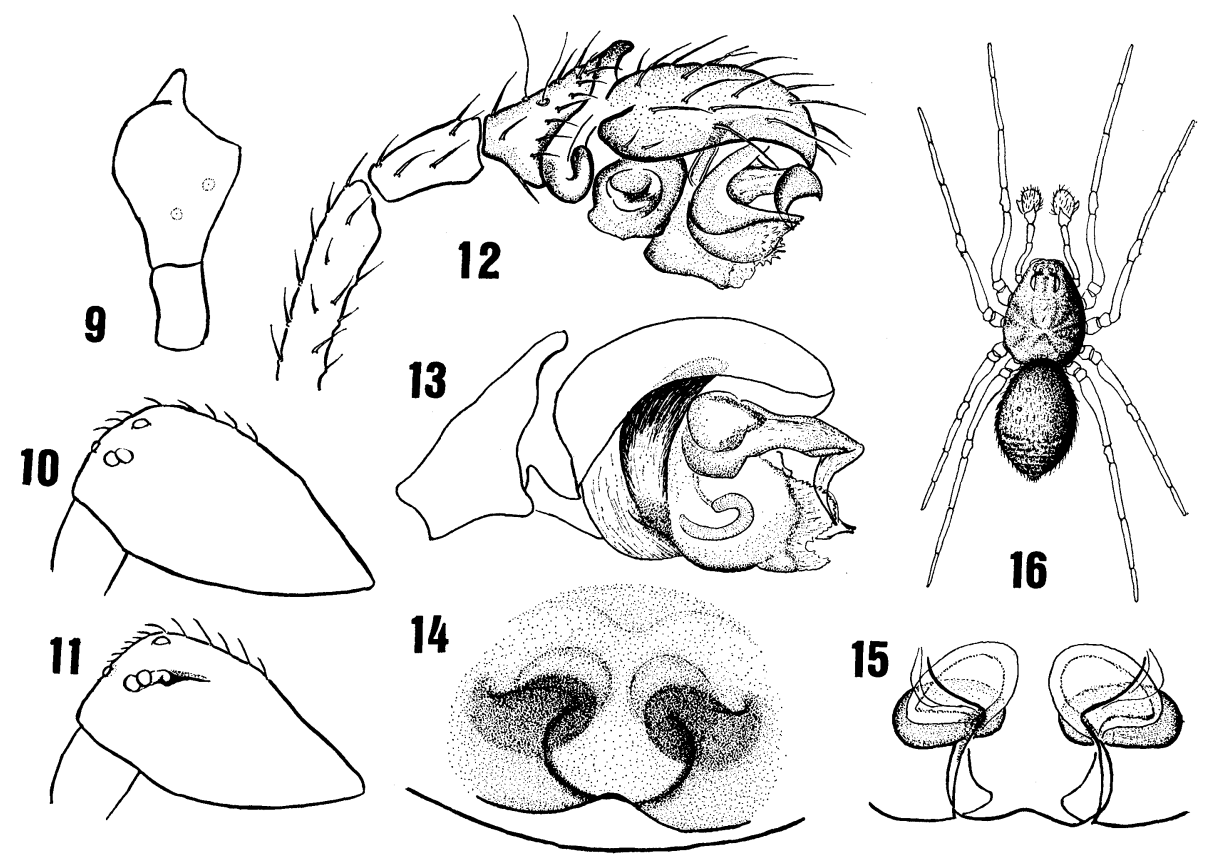

Figs. 9-16. Tapinosyba oiwa n. sp. 9\} right palpal tibia dorsal; 10 profile

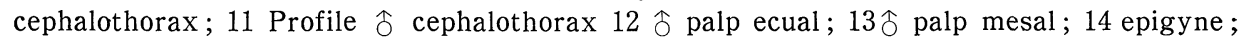
15 genitalia; $16 \hat{\delta}$ body dolsal.

I-III with a trichobothrium, its position; Tm I 0.42, Tm II 0.36, Tm III 0.36 . Tarsal claws on I-II weakly developed several teeth.

Measurements of legs are as follows:

\begin{tabular}{cccccc}
\hline Legs & Fem. & Pat. \& Tib. & Met. & Tar. & Total \\
\hline I & 0.44 & 0.53 & 0.28 & 0.26 & 1.51 \\
II & 0.41 & 0.46 & 0.25 & 0.24 & 1.36 \\
III & 0.35 & 0.38 & 0.23 & 0.23 & 1.19 \\
IV & 0.45 & 0.59 & 0.28 & 0.24 & 1.56 \\
\hline
\end{tabular}

Abdomen pale gray.

Male Palp. Femur gently curved inward and somewhat widened distally. Tibia dorsally produced into a short triangular apophysis which terminates in a black and downward toward the cymbium. Paracymbium slender and very strongly curved. Tegulum protuberant ventrally, with long tegular membrance. The embolic division broad, rounded at radical part, distally bent at right angle 
and sharply pointed.

Female (paratype). Body length $1.5 \mathrm{~mm}$. Similar to male in form and color. Head without sulci. The epigynum consists of a rounded convex plate.

Type-series. Holotype: $\hat{\delta}$, allotype: 우 14-V-1977, Ginzandaira, Ashio, Tochigi Pref., H. SAITo leg.

Paratype: 11\}, 7 우, same data as the holotype; $7 \hat{\delta}, 6$ 우, 5-V-1979, do., H. SaIto leg.; 1今, 3우,6-V-1973, Mt. Gyodou, Ashikaga, Tochigi Pref., H. SAIto leg. ; 4 ㅇ, 10-VI-1973, Nagusa, Ashikaga, Tochigi Pref., H. OHKawa \& H. Saito leg. ; 8ㅇ, 26-V-1979, Mt. Ohiwa Ashikaga, Tochigi Pref., H. SAIto leg.; 12 우, 16-VI-1970, Konuma (Mt. Akagi), Gunma Pref., H. SAITo leg.

The holotype and one of the paratypes are deposited in the collection of the Arachnologica Society of East Asia, Ohtemon-Gakuin University, Osaka.

Distribution. Japan (Honshu).

Remarks. This species is related to $T$. praecox (Cambr.), but differs markedly from it in the structure of make palp and in the female genitalia.

\section{摘 要}

\footnotetext{
斎藤 博（†326栃木県足利市旭町3-772）：日本産 Tapinocyba 属（コサラグモ科） 2 新種の記 載。

関東地方北部に産する Tapinocyba 属の 2 新種 $T$. silicultrix (ヤマジコナグモ) と T. oiwa (オオイワヤマジョナグモ) を記載した。これらの種はともにヨーロッパに産する種々類似するが, それぞれの今の palp や守の epigyne や genitalia の形態により分類される。

因に，本属の種については，すでに八木沼（1963）により秋吉台洞窟群より確認され，わが国に も産することが知られている。
}

\section{Main Literature}

Bonnet, P., 1958. Bibliographia Aranearum. 2: 3027-4230. Toulouse.

Crosby, C.R. \& Bishop, S.C., 1933. American spiders: Erigoneae, Male with cephalic pits. Ann. Ent. Soc. America, $26: 105-182$.

Georgescu, M., 1973. La position systematique des genres Tapinocyba E. Simon, La description d'une nouvelle espece: Tapinosyba silvestris. Trav. Inst. Speol. E. Racovitza 12 : $127-134$.

Kolosvary, G., 1934. 21 neue Spinnenarten aus Slovensko, Ungarn unt aus der Banat. Foria zool. Hydrobiol., 6(1) : 12-17.

Millidge, A.F., 1977. The conformation of the male palp organs of Linyphiid spiders, and its application to the taxonomie and phylogenetic analysis of the family (Araneae : Linyphiidae). Bull. Br. arachnol. Soc., 4(1) : 1-60. 
1979. Some erigonine spiders from southern Europe. Bull. Br. arachnol. Soc., $4(7): 316-328$.

Simon, E., 1884. Les Arachnides de France., 5(3): 421-885.

1926. Les Arachnides de France., 6(2) : 309-532.

WIEHle, H., 1960. Spinnentiere oder Arachnidea (Araneae) XI. MicryphantidaeZwergspinnen. Tierwelt Dt1. 47:1-620.

Wunderlich, J., 1970. Zur Synonymie einiger Spinnen-Gattungen und -Arten aus Europa und Nordamerika (Arachnida: Araneae). Senckenberg. biol., 51 (5/6) : 403-408.

Yaginuma, T., 1963. Spiders from limestone caves of Akiyoshi Plateau. Bull. Akiyoshidai Sci. Mus., (2) : 49-62. (in Japanese, with English descriptions.) 